\title{
A World of Summer and Autumn: The Romano-British to Early Medieval Weald and Signs of Continuity
}

\author{
Andrew Margetts
}

Recent developer funded projects conducted by Archaeology South-East, the contracting division of the Centre for Applied Archaeology (CAA) have, over the last decade or so, begun to fill a void in our knowledge of one of the most archaeologically under-researched areas in Britain. It is becoming clear that rather than being a marginal landscape beyond more habitable zones, the Weald of South-East England was actually one which experienced significant and widespread periods of colonisation. By examining the evidence from a number of sites the author is starting to explore the area's early medieval landscape, which is beginning to show degrees of continuity from Roman and prehistoric times. This brief update is intended to highlight a revolution in our understanding of South-East England in the centuries surrounding the Roman Conquest. The ongoing research is a case study in landscape analysis and landscape regression. Results will be discussed in forthcoming articles as well as a 'Spoilheap monograph' due for release this year (Margetts 2018).

The Iron Age - Romano-British Weald The area is traditionally divided between the elevated, predominantly sandstone, High Weald and the largely clay Low Weald. The Greensand Ridge that surrounds this inner core has, on the other hand, been both grouped with the Weald and defined as a distinctive character area within its own right (Figure 1). The Weald, a 'sub-province' within Roberts and Wrathmell's 'south-eastern province', is characterised by historically high densities of settlement dispersion (2000: 8, figure 3). It has been traditionally seen as a 'marginal' landscape, with a distinctive economy and history of colonisation. The origins

Archaeology South-East (UCL), 2 Chapel PI, Portslade, Brighton, BN41 1DR, UK

a.margetts@ucl.ac.uk of Wealden dispersion and the perception of this marginality may in part be linked to the prevalence of woodland, unrewarding soils and a history of pastoralism rather than arable farming. The antiquity of the landscape and its potential as an archaeological resource was touched upon by the South East Research Framework conference (SERF 2007), although the motivation to explore the origins of such landscapes has been more deeply felt in other regions, such as the south-west, that share a dispersed nature to their settlement history (e.g. Webster 2008: 287).

As recently as 2016 with the publication of the results of the Roman Rural Settlement Project (Allen et al. 2016; Smith et al. 2016) and 2003 when Peter Brandon produced his seminal landscape history The Kent and Sussex Weald (Brandon 2003), it was impossible 


\begin{tabular}{|c|c|c|c|c|c|c|}
\hline \\
\hline \multicolumn{7}{|c|}{ Choice_1 Choice_2 Choice_3 Choice_4 Choice_5 Choice_6 } \\
\hline Subj_1 & 2 & 2 & 2 & 2 & 2 & 2 \\
\hline Subj_2 & 1 & 2 & 3 & 2 & 2 & 2 \\
\hline Subj_3 & 3 & 4 & 3 & 2 & 2 & 1 \\
\hline Subj_4 & 4 & 3 & 1 & 1 & 1 & 2 \\
\hline Subj_5 & 1 & 2 & 3 & 4 & 3 & 1 \\
\hline Subj_6 & 1 & 2 & 1 & 2 & 1 & 2 \\
\hline Subj_7 & 1 & 2 & 3 & 4 & 4 & 3 \\
\hline Subj_8 & 4 & 2 & 1 & 3 & 2 & 3 \\
\hline Subj_9 & 1 & 2 & 1 & 2 & 3 & 4 \\
\hline Subj_10 & 4 & 2 & 2 & 1 & 3 & 1 \\
\hline
\end{tabular}

Figure 1: South-East England showing the pays or character areas of the region. Graphic prepared by A. Margetts.

to point to significant Iron Age or RomanoBritish Wealden settlement. Discussion was typically limited to a few villas, waystations, a handful of hillforts and Roman industry. This scarcity of evidence has been borne out by other studies (Drewett, Rudling and Gardiner 1988; Taylor 2007) and it has become the prevailing view that the Weald's gap in evidence reflects a genuine absence of sites (Taylor 2007: 51). Since the introduction of PPG16 in the 1990's, however, the increase in developer funded work has produced an exponential growth in our knowledge of the area. This is particularly so for the centuries immediately surrounding the Roman Conquest. Perhaps one of the greatest contributions to this growth in knowledge has come from a number of large scale residential developments in the areas of Horsham, West Sussex and Horley, Surrey (Margetts 2018; Swift in prep). Collectively these interventions have given us a good understanding of the northern Weald in the centuries surrounding the turn of the $1^{\text {st }}$ millennium. They have provided information with the potential to contribute to both regional and national research agendas.
What has emerged is a model for the widespread colonisation of the Wealden interior. This appears to have begun in the earlier Middle Iron Age and continued until the mid- $2^{\text {nd }}$ century $A D$ when decline in the traditional pattern of settlement, possibly linked to the growth of villa estates, becomes apparent. The significant evidence for preceding Middle Iron Age activity has been viewed by Hamilton (2007) as proof of a renewed 'uptake of the Weald Clay', which is in marked contrast to our understanding of much of the rest of southern Britain. Beyond the South-East, expansion into more 'marginal' zones does not appear to have taken place until the later part of the period (Haselgrove 1999: 129; Hill 2002, 2007). The evidence from Sussex suggests that demographic changes from the 4th century BC were based on population dispersal rather than population pressure and expansion (Hamilton 2007: 87), perhaps facilitated by the creation of new hillforts which played a role in uniting dispersed communities (ibid: 85-6). It may be no coincidence that at this time we have evidence for the first hillfort construction in the Weald, as well as 
on the adjacent Greensand (e.g. High Rocks, Holmbury and Hascombe).

As the Iron Age progressed there is increasing evidence for widespread settlement of the Wealden interior. Enclosure and land division became far more common and this bounding of settlements marked a distinct break with earlier traditions of open clusters of roundhouses. By the $1^{\text {st }}$ century, the enclosures were clearly components of a landscape divided by fairly continuous field boundaries. This was a well utilised and cohesive landscape of settlement enclosures dispersed within small fields. People were taking advantage of well-watered, low-lying streamside environments, which would have been well suited to the raising of livestock. We have been fortunate to investigate a number of silted watercourses during our exploration of the northern Weald and pollen evidence has shown that by the $1^{\text {st }}$ century AD activity was taking place in cleared grassland environments with stands of trees. This was not the continuous impenetrable woodland imagined by earlier writers (Margetts 2018).

The emerging settlement pattern of the Low Weald in the 1st-century $\mathrm{AD}$, therefore, seems to be one of a dispersed nature. Small rectilinear enclosures existed in either low-lying or slightly elevated positions with access to watercourses, routeways and longdistance boundaries. They appear to have been largely laid out on a north-south or north-east-south-west orientation and bear a resemblance to so-called 'droveway' or 'ladder enclosures'. The post-Conquest landscape appears to have been a direct continuation of preceding Late Iron Age patterns. Apart from roadside settlements and rare villas, rural Roman activity largely consisted of the modification of landscape features founded during the preceding phase. There was a dramatic change in emphasis during the mid- $2^{\text {nd }}$ century $\mathrm{AD}$, however, when there is little evidence of non-industrial occupation and little pottery was being deposited in agricultural boundaries. Despite this, the landscape was maintained to some degree, as ditches relating to earlier enclosures remained at least partially open to receive material at the very end of the Roman period. The lack of ceramic material may not be indicative of complete abandonment but rather perhaps of a switch in the emphasis of activity. The deposition of pottery within ditch features can be linked to occupation but also to arable activity, with broken pottery incorporated into manure heaps and middens within farmyards and then spread on arable fields to improve fertility. The process of manuring may thus have been an important factor in the accumulation of pottery within field boundary ditches. A switch in emphasis from occupation and/or cereal cultivation and a move towards pastoralism would therefore have a negative effect on the quantities of pottery in such features.

The Late Roman period witnessed a final contraction in land use with a general lack of maintenance of ditch systems and the gradual abandonment of the Early-Middle Romano-British agricultural system. The main identifiable activity is the deposition of refuse in the upper levels of earlier ditches; a hiatus in alluviation of watercourses may also be linked to this phase.

\section{Early Medieval Signs of Continuity}

Questions surrounding whether there was, or was not, any Roman or pre-Roman continuity into the landscape of the medieval period has occupied historical geographers and landscape archaeologists for decades. To date, Professor Stephen Rippon's Fields of Britannia project (Rippon, Smart and Pears 2015) comprises the most thorough attempt to gauge how far the countryside of Roman Britain has survived. The aim of the project was to study the extent of possible continuity, or discontinuity, in the physical fabric of the countryside. This was attempted by examining the relationship between Romano-British landscapes and their medieval successors. One of the ways this was achieved was by overlaying historic landscape evidence as depicted on Ordnance Survey 1st edition maps with excavated Roman and medieval land division. In this way it could be seen whether the evidence had a completely different, unrelated relationship, with the historic landscape, an orientated one, showing 
signs of possible continuity, or an aligned relationship showing a form of continuity.

In order to explore signs of possible continuity within the Weald it is necessary to understand the area's early medieval landuse and the mark this left on the countryside. For much of the Anglo-Saxon period the area existed within a system of transhumance. In the summer and autumn, herders would use droveways to move animals from parent settlements located in the more favourable arable areas to detached seasonal settlements within the Wealden interior. The area of parallel routeways that developed has been previously investigated by Diana Chatwin and Mark Gardiner (2005). They have shown the parallel tracks and long-distance field boundaries which characterise the area to be occupied by intervening blocks of northeast-southwest orientated fields. This pattern was in place by at least the $10^{\text {th }}$ century as manorial, parochial and hundredal boundaries respect this earlier land-division. The droveways which form the major axial elements within this system have often been presumed to be of early medieval date as they, and the method of resource exploitation they represent, are reflected in contemporary Anglo-Saxon charters and place-name evidence. It has often been postulated that these droveways may have had earlier origins, although their true date has never been tested.

Perhaps the most significant finding of the work that has taken place in the northern Weald, is the apparent similarity between the alignment of Late Iron Age/Early Roman fields and those of today. This pattern was most noticeable at the larger sites of North-East Horley and Wickhurst Green (Margetts 2018; Swift in prep) where Late Iron Age and Early Romano-British features were found to have an aligned or orientated relationship with the historic landscape (Figure 2). Within much of the Weald, $19^{\text {th }}$ century cartographic evidence has the ability to provide a strong echo of the landscape as

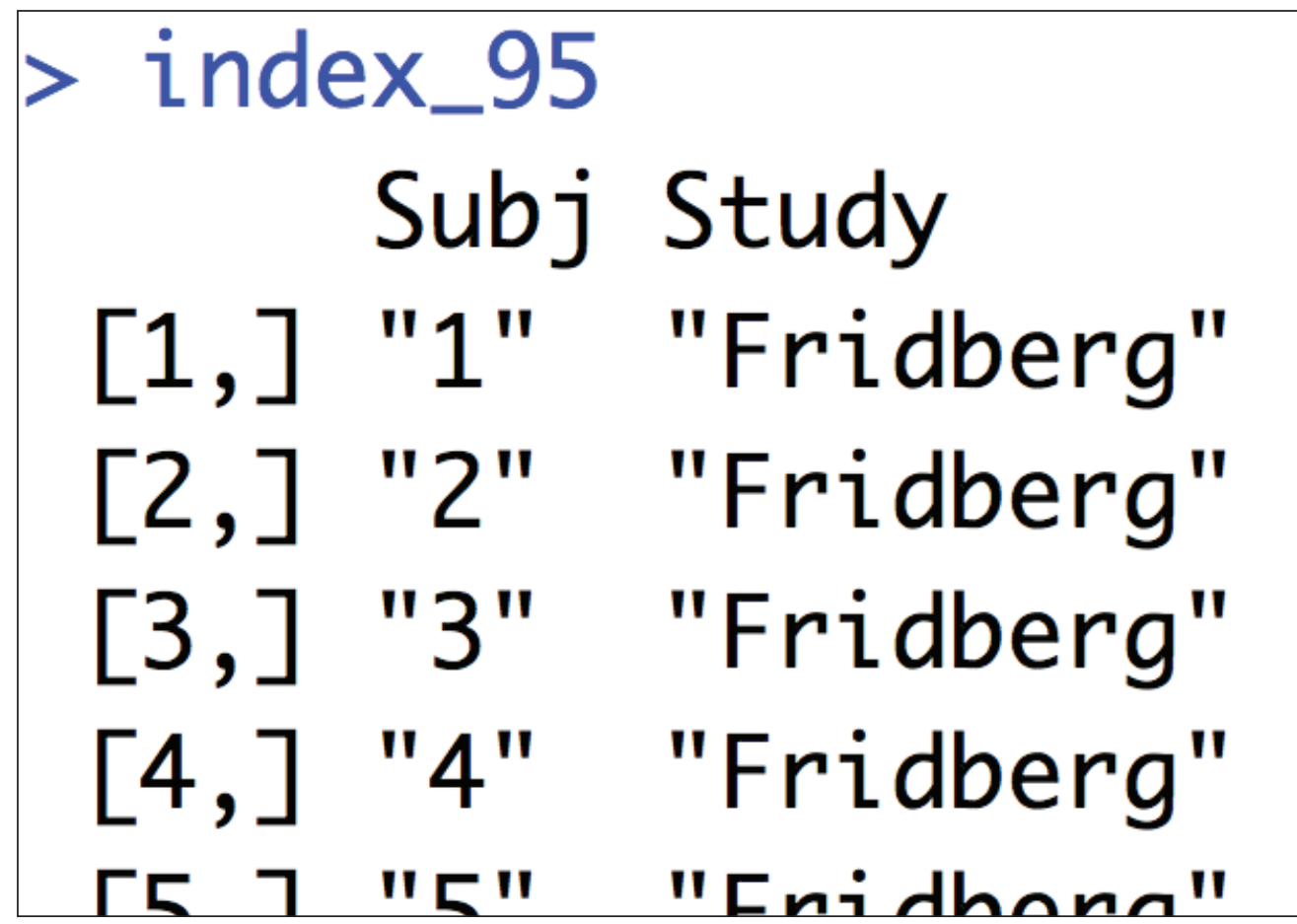

Figure 2: Excavated evidence from Wickhurst Green (left) and North-East Horley (right) overlain on Ordnance Survey $1^{\text {st }}$ edition map 1874 and 1875-6; showing signs of possible landscape continuity from the Roman to medieval period. Graphic prepared by A. Margetts. 
it would have appeared in the late medieval period and here we can also see how some of these late prehistoric boundaries mirror later land-division and routeways within the sites.

It may be that features laid out during the centuries surrounding the Conquest continued to have a strong influence on the landscape of the medieval period and that of today. At Wickhurst Green, we can see that the long spinal boundary of a ladder enclosure and its associated paddocks are strongly aligned with later land-division of medieval date shown on the Ordnance Survey $1^{\text {st }}$ edition map. At Horley too, there was a strong association between early Romano-British and later land division. Here, the purple lines are ditches of $1^{\text {st }}$-century date, whereas the green lines are medieval. We can see that not only is the Roman land-division aligned with later field boundaries, but that an example that was well-dated by Roman pottery in the north-east almost certainly relates to the earlier boundary of an extant field.

\section{Conclusion}

From the evidence gleaned through the excavation of a number of sites in the northern Weald it is possible to suggest that the grain of the area's historic landscape was in place by the $1^{\text {st }}$ century AD. As such the excavated evidence may indicate signs of possible continuity between the landscape of the Roman period, the subsequent medieval period, and that of today. The strong influences that hydrology and topography have had on the formation of the region's landscape makes this apparent continuity open to debate. This is something I am going to explore in a number of forthcoming papers and a new monograph to be published in the late spring on the Wickhurst Green site (Margetts 2018).

\section{Competing Interests}

The author has no competing interests to declare.

\section{References}

Allen, M, Blick, N, Brindle, T, Evans, T, Fulford, M, Holbrook, N, Richards, J D and Smith, A 2016 The rural settlement of Roman Britain: an online resource. DOI: https://doi.org/10.5284/1030449

Brandon, P 2003 The Kent and Sussex Weald. Chichester: Phillimore and Co Ltd.

Chatwin, D and Gardiner, M 2005 Rethinking the early medieval settlement of woodlands: evidence from the western Sussex Weald. Landscape History, 27: 31-49. DOI: https://doi.org/10.1080/01 433768.2005.10594570

Drewett, P, Rudling, D and Gardiner, M 1988 The south-east to $A D$ 1000. London: Longman.

Hamilton, S 2007 Cultural choices in the 'British Eastern Channel Area'. In: Haselgrove, C and Moore, T (eds.), The later Iron Age in Britain and Beyond, 81-106. Oxford: Oxbow Books.

Haselgrove, C 1999 The Iron Age. In: Hunter, $\mathrm{J}$ and Ralston, I (eds.), The Archaeology of Britain, 113-134. London: Routledge.

Hill, J D 2002 Just about the potter's wheel? Using, making and depositing middle and later Iron Age pots in East Anglia. In: Woodward, A and Hill, J D (eds.), Prehistoric Britain: The ceramic basis, 143-160. Oxford: Oxford University Press.

Hill, J D 2007 The dynamics of social change in Later Iron Age eastern and south-eastern England c.300 BC-AD 43. In: Haselgrove, $\mathrm{C}$ and Moore, $\mathrm{T}$ (eds.), The Later Iron Age in Britain and Beyond, 16-40. Oxford: Oxbow Books.

Margetts, A 2018 Wealdbcera: Excavations at 'Wickhurst Green', Broadbridge Heath and the landscape of the West Central Weald. Archaeology South-East (UCL)/Surrey County Archaeological Unit. Spoilheap Monograph Series 18.

Rippon, S, Smart, C and Pears, B 2015 The Fields of Britannia. Oxford: Oxford University Press.

Roberts, B K and Wrathmell, S 2000 An Atlas of Rural Settlement in England. London: English Heritage.

SERF 2007 South East Research Framework. Available at: http://www.kent.gov.uk/ leisure-and-community/history-andheritage/south-east-researchframework [Last accessed 11 January 2018] 
Smith, A, Allen, M, Brindle, T and Fulford, M 2016 The Rural Settlement of Roman Britain. London: The Society for the Promotion of Roman Studies. Britannia Monograph Series 29.

Swift, D In prep Iron Age and Romano-British archaeology at Horley, Surrey. Archaeology South-East (UCL)/Surrey County Archaeological Unit. Spoilheap Monograph Series.
Taylor, J 2007 An atlas of Roman rural settlement in England. York: Council for British Archaeology. Research Report 151.

Webster, C J 2008 South West Archaeological Research Framework: A Research Agenda for Archaeology in South West England. In: Webster, C J (ed.), The Archaeology of South West England, 269-291. Somerset County Council.

How to cite this article: Margetts, A 2018 A World of Summer and Autumn: The Romano-British to Early Medieval Weald and Signs of Continuity. Archaeology International, 21(1), pp. 89-94. DOl: https://doi.org/10.5334/ai-377

Submitted: 03 April $2018 \quad$ Accepted: 16 May $2018 \quad$ Published: 05 December 2018

Copyright: (c) 2018 The Author(s). This is an open-access article distributed under the terms of the Creative Commons Attribution 4.0 International License (CC-BY 4.0), which permits unrestricted use, distribution, and reproduction in any medium, provided the original author and source are credited. See http://creativecommons.org/licenses/by/4.0/.

]u[ Archaeology International is a peer-reviewed open access journal published by Ubiquity Press. 